\title{
Social Intelligence Contribution in Perspective Learning Outcomes of Elementary School Social Science Subject
}

\author{
Eko Purwanti \\ Elementary School Teacher of Education Department \\ Semarang State University, Indonesia \\ purwanti17@mail.unnes.ac.id
}

\author{
Pipit Diah Noviana \\ Elementary School Teacher of Education Department \\ Semarang State University, Indonesia \\ noviana.pdn@gmail.com
}

\begin{abstract}
Many students assume that the Social Science Subject lesson students memorize so it is not desirable. One solution to this problem is to see social intelligence from a different perspective. Many internal and external factors that affect the results of social studies one of which is social intelligence. This study aims to examine the contribution of social intelligence in the perspective of social science subject learning outcomes. This study used correlational research design with quantitative approach. Sampling techniques using simple random sampling. the data collection techniques in this study were realized by the use of questionnaires, documentation, observation, and interviews. Test instrument through validity and reliability test. The data were analyzed by using several techniques, including descriptive statistical analysis, correlation analysis, and regression analysis. The results showed that there was a positive and significant relationship between social intelligence to social science subject learning outcomes with strong category and higher contributions which means that the students' social intelligence play a role in improving student learning outcomes, especially in social studies subject. The final conclusion is that there is a social intelligence have contributed in perspective the results of social studies class IV SDN Pierre Tendean Cluster, Kaliwungu-Kendal Regency.
\end{abstract}

Keywords: perspective; social science subject learning outcomes; social intelligence

\section{INTRODUCTION}

Basically, each individual has the intelligence. However, the intelligence of the individual is different from another individual. Intelligence is not only in terms of the intellectual. Gardner (Subini, 2012) formulated the eight intelligences are linguistic, logical mathematical intelligence, naturalistic intelligence, kinesthetic intelligence, visual spatial intelligence, musical intelligence, interpersonal / social, and intrapersonal intelligence. Data scientists Honeywill (2015) stated social intelligence is a combination of self-awareness and social consciousness, the evolution of social beliefs and attitudes, as well as the capacity and ability to manage complex social change.

Social intelligence is the ability to capture a sense of purpose, motivation, and the will of others (Subini, 2012). Individuals have a high level of social intelligence if it meets the following indicators, including the ability to solve problems, the ability to establish relationship / interactions, genuineness, empathy, communication, and synchronization.

Social problem solving, interaction, and communication is closely related to social studies, who has a substance of social phenomena. Taneo (2010) mentions Social Science Subject the science that combines certain concepts from the social sciences and other sciences to be processed and adapted to the teaching program. Social Science Subject (IPS) is also defined as the science that studies the social sciences, humanities, and other human activities in order to provide insight and understanding to the learners.

Students' ability to interact, communicate and solve the so-called learning results in the output will achieve the expected indicators in social studies. The learning result is a tool that can be used to measure the level of student understanding. The results obtained studying is something a person because of his efforts in various areas of life so that it appears a change. Learning outcomes to be the end of a learning process or the result of the interaction of action learning and teaching action.

Each student learning outcomes differ between students of the other students. The level of learning results obtained is influenced by several factors. There are two factors that affect learning outcomes by Slameto (2013), which is a factor of the (internal) and external factors (external). Factors of the (internal) include physical factors (health and disability); psychological factors (intelligence, attention, interests, talents, motives, maturity, readiness); and the fatigue factor. While external factors (external) factors include family, school and community.

Social intelligence raises a variety of impacts on both the aspects and social activities as stock students in his duties as social beings in society in the future. Kanaria research results (2014) on the implications of social intelligence on social science subject learning outcomes has a very strong contribution. The higher the social intelligence of the students, the better academic viewed from the perspective of social science subject learning outcomes.

Results Rahim (2018) show students that have a high social intelligence will be able to understand the feelings and desires, accept what is, understand the needs, cares, and able to adapt to a person or interlocutor in certain situations. These capabilities are indispensable in group learning activities. The success of the students in learning groups contribute to optimal learning achievement. Different facts about the influence of social intelligence to the learning outcomes indicated by studies Baggiyam IPS (2017) in his study of social intelligence in 
relation to the learning outcomes indicate that mild or weak relationship of each variable is social intelligence and learning outcomes.

Social conflicts hamper the individual to develop a mature social world. As a result of this individual to be lonely, feeling of worthlessness, and isolating themselves. Ultimately leading to depression and loss of the individual is the meaningfulness of life, as proposed by Frankl (Azwar, 2015) as symptom oogenus existential neurosis or vacuum. Individuals who have limited social interaction will be many obstacles when entering the vast ore environments such as school or community.

For example, the case bullying which often happens even in the activity of students in the school. Based on research by the National Commission for Child Protection in 2017 , there were $84 \%$ of children in Indonesia have experienced violence in school. Other conditions related social intelligence will emerge when students work in groups then shame lead away from the joint activities. Adolescents who are unable to cooperate with peers will tend to be set aside and not get an important role in later life. Not to mention when it will reach adulthood and have to start a career in Integration where she worked. Individuals need the skills to build relationships, create new relationships and maintain contact with the relationship as well.

Problems related to social intelligence also occurs in the fourth grade SDN Pierre Tendean Cluster, Kaliwungu Sub-district Kendal Regency. Based on observations and interviews at the pre-study, the results of social studies students have not been optimal, meaning that approximately $40.27 \%$ of the 149 students received grades below minimum KKM or completeness limit. Some students have not been active and participate in learning, communication some students are still low, and the lack of appeal of learners, and some students have a mental or low confidence. The identification of the results indicates that the social intelligence of students in charge of social studies, especially history is still relatively low.

\section{METHOD}

The research method of this study was quantitative research with correlational research design. Correlation research is a research conducted by researchers to determine the contribution of social intelligence in social science subject learning outcomes. Perspective of this research aimed to determine the contribution of social intelligence in the perspective of social science subject learning outcomes with simple random sampling technique.

The samples in this study were 117 fourth grade students of SDN Pierre Tendean Cluster, Kaliwungu Subdistrict Kendal Regency. The variable in this study is the independent variable (social intelligence) and the dependent variable (social science subject learning outcomes).

Data collection techniques in this study through questionnaires to the data of social intelligence, while documentation for the data results of social studies and supported by data from observations and interviews to the fourth-grade teacher. Prior research instruments used, researchers tested the validity and reliability of the instrument. Instruments tested in advance to the 30 respondents in elementary others are not used as samples to minimize the leakage point statement. The trial aims to determine whether the instrument is appropriate instruments (valid and reliable) or not. After knowing the valid and reliable instrument, then the election to point declaration valid and reliable to measure the research variables with the criteria $r$ count larger than $r$ table is 0.361 (standard error of 5\%).

The prerequisite test of data analysis was done by normality test and linearity test first. After that, it proceeded with the hypothesis test consisting of simple correlation analysis and simple linear regression analysis.

\section{RESULT}

Results of research on social intelligence contribution of social science subject learning outcomes grade IV SDN Pierre Tendean Cluster, Kaliwungu Subdistrict Kendal Regency cover several things as follows.

\section{Descriptive Analysis Results}

\section{Descriptive analysis Variable Social Intelligence (X1)}

Data descriptive analysis of social intelligence obtained from the student questionnaire respondents consisted of 30 statements with four possible answers (Likert Scale). Based on the obtained data processing results of descriptive analysis of social intelligence questionnaire as follows (Table 1).

Table 1

Results of Student Questionnaire Social Intelligence

\begin{tabular}{|c|l|c|c|c|}
\hline $\begin{array}{c}\text { Interval } \\
\text { Scores }\end{array}$ & Classification & Frequency & $\begin{array}{c}\text { Percentage } \\
(\mathbf{\%})\end{array}$ & Average \\
\hline $99-120$ & Very high & 99 & $85 \%$ & \multirow{2}{*}{$\mathbf{1 0 7 . 4 3}$} \\
\cline { 1 - 4 } (Very \\
high)
\end{tabular}

Table 1 shows the results of the frequency distribution of social intelligence are 99 students were classified as very high at $85 \%, 18$ students or $15 \%$ in the classification of high, and 0 students or $0 \%$ in the classification of medium and low, meaning no students are in classification medium or low.

\section{Descriptive analysis Variable of Social Science Subject Learning Outcomes (Y)}

The students' learning outcomes data were obtained from the cognitive domain of IPS subject. Specifically, they were derived from the documentation of midterm test scores. Moreover, based on data processing, it was obtained the results as follows (Table 2).

Table 2

\begin{tabular}{|c|c|c|c|c|}
\hline Category & Value & Frequency & $\begin{array}{c}\text { Percentage } \\
(\%)\end{array}$ & Average \\
\hline Very good & $86-98$ & 48 & $41 \%$ & \multirow{4}{*}{$\begin{array}{c}78.76 \\
\text { (Good) }\end{array}$} \\
\hline Well & $74-85$ & 27 & $23 \%$ & \\
\hline Enough & $62-73$ & 36 & $31 \%$ & \\
\hline Less & $50-61$ & 6 & $5 \%$ & \\
\hline \multicolumn{2}{|c|}{ total } & 117 & $100 \%$ & \\
\hline
\end{tabular}

Based on Table 2, there were 48 students (41\%) scored in the excellent category, 27 students or $23 \%$ gain value in either category, 36 students or $31 \%$ gain value in 
the category enough, and in the poor category there are 6 students which is $5 \%$ of the total students.

\section{Prerequisite Data Analysis Test Normality test}

Normality test is done to determine whether the variable social intelligence and social science subject learning outcomes normal distribution or not. Testing normality done using the Kolmogorov-Smirnov Testaided analysis program SPSS 21 data normality test results obtained, namely 0,064 social intelligence and learning outcomes data for 0,959 IPS. Thus, it can be concluded that the two variables, namely the study of social intelligence and learning outcomes IPS normal distribution because of the significant value of more than 0.05 .

\section{Linearity test}

Linearity test aimed to determine whether the two variables had a linear relationship or not. Linearity testing using SPSS 21 with the calculation Test for Linearity at significance level of 5\% linearity test results obtained with the data of social intelligence and social science subject learning outcomes is 0,100 . Thus, we can conclude that the social intelligence to learning outcomes IPS has a linear relationship because the significance is more than 0.05 .

\section{Hypothesis testing Product Moment Correlation (Simplified)}

Simple correlation analysis was used to test the hypothesis whether there is any relationship between the two variables of the study using SPSS 21 and formula Product Moment Correlation. The results of these calculations are as follows (Table 3).

Table 3

Summary of Product Moment Correlation

\begin{tabular}{|c|c|c|c|c|}
\hline variables & Sig. & $\begin{array}{c}\text { Pearson } \\
\text { Correlation }\end{array}$ & $\begin{array}{c}\mathbf{R} \\
\text { tabel }\end{array}$ & $\begin{array}{c}\text { Categories } \\
\mathbf{r}\end{array}$ \\
\hline $\begin{array}{c}\text { X1 with } \\
\text { Y }\end{array}$ & 0,000 & 0.665 & .180 & Strong \\
\hline
\end{tabular}

Table 3 shows that there is a strong relationship between social intelligence (X1) with the results of social studies $(\mathrm{Y})$ with $\mathrm{r}_{\text {count }}$ of 0.665 and is positive and significant (sig. $0.000<0.05$ ). This means that the higher the social intelligence of students, the higher the learning outcomes IPS that Ha accepted that there is a positive and significant relationship with the social intelligence learning outcomes IPS. The coefficient of determination of social intelligence on learning outcomes IPS is equal to $44.22 \%$, meaning that social intelligence a contribution of $44.22 \%$ to the social science subject learning outcomes, rest influenced by other factors outside the research.

These results are supported by previous studies conducted Paulina (2017) with the title of Media Influence Learning and Interpersonal intelligence on Yield Learning English Students STIPAS Tahasak Pambelum Danum Palangkaraya. The results showed that $\mathrm{Q}_{\text {count }}$ of 10.3, meaning that interpersonal influence on learning outcomes.

Then other studies, namely by Daniyati (2017) showed no association interpersonal skills and learning achievement with contributions of $1.64 \%$ and no correlation interest in learning and learning achievement, contributing $6.15 \%$.

Further research by Jerome Popp (2017) showed that someone with a high social intelligence is very easy to feel empathic, more easily understand what other people think and their intentions, as well as better understand and interpret the comments of people who interact with it. Likewise, a study conducted by Kriemeen (2017) concluded there is a correlation between social intelligence and social creative behavior with positive and significant correlation.

Social intelligence are internal factors that affect learning outcomes. Social intelligence faster impact than people receive information and solve the problem, although there are other factors that come into play. Djamarah (2015) argues that intelligence (intellectual, emotional, spiritual, and social) are considered determinants of success or failure of students in the school.

\section{Simple Linear Regression Testing}

Simple regression in this study has the objective is to predict the dependent variable $(\mathrm{Y})$ if the independent variable (X) are known (Riduwan, 2013). The result of the calculation is simple linear regression analysis can be seen in the following Table 4.

Table 4

Results of simple linear regression analysis

\begin{tabular}{|c|c|c|c|c|}
\hline \multicolumn{4}{|c|}{ Results of simple linear regression analysis } \\
\hline Variables & R Square & Sig. & $\begin{array}{c}\text { Regression } \\
\text { Coefficients }\end{array}$ & Constants \\
\hline X1 with Y & $\begin{array}{c}0.443 \\
(44.3 \%)\end{array}$ & 0,000 & 0,844 & -11.950 \\
\hline
\end{tabular}

Table 4 shows that social intelligence relationship (X1) with the results of social studies accounted for $44.3 \%$, sig. $0.000<0.05$, regression coefficient of 0.844 , and the constant -11.950 so that the regression equation is $\breve{Y}=-11.950+0,844 \mathrm{X} 1$.

\section{DISCUSSION}

Based on calculations, the social intelligence contribution in social studies learning outcomes as very strong with a correlation coefficient of 0.665 . In addition, the contribution of social intelligence into perspective the results of social studies contributed by $44.3 \%$. This means that social intelligence has the effect of $44.3 \%$ and the rest influenced by other factors not examined, both external factors and internal factors.

Social intelligence is one of the internal factors that impact on learning outcomes of individuals. Social intelligence is the ability of a person in the social life of individuals that includes communication, interaction, and establish a social relationship. Djamarah (2015) states intelligence including social intelligence are considered determinants of success or failure of students in the school. This opinion was reinforced Susanto (2013) that social intelligence affects the fast or slow a person receives information and solve the problem, although there are other factors that come into play.

Thorndike (in Goleman, 2018) states other social intelligence with academic skills as well as an important part that scored a success in practical everyday life. The 
opinion is in line with the purpose of IPS by Taneo (2010) were able to adjust to the environment. On the other hand, Dalyono (2012) assert that individuals with good intelligence (intellectual, emotional, spiritual, and social), the study results tend to be good, and if the individual has the intelligence is below average in the study result is also not good. The role of social intelligence in learning is very important to the success of every individual both within the school and in everyday life.

Following successive social intelligence indicators ranging from the most visible is as follows: communication; empathy; authenticity; having a relationship; synchronization; and problem solving. Communication indicator the biggest influence aspects of social intelligence in the perspective of social science subject learning outcomes. Afrianti (2015) states in every communication process, each individual will express his feelings. Non-disclosure of feelings, communication that occurs will be empty. Expression of feelings is an important element in the process of meaningful communication. The more open-feeling towards others. Then deepen the relationship. In some students, disclosure of this feeling does not occur effectively so that it does is immediately turned the conversation that is not interesting without explaining how she felt when she received it. This means that students often do not open with his feelings.

Students with high social intelligence can more easily interact, connect, and communicate in the learning activities even actively participate in class activities IPS study results obtained are also higher. The status and role of social intelligence is very important as a factor supporting children's learning outcomes obtained. Therefore, as educators need to help the social development of each of their students in order to help improve learning outcomes.

\section{CONCLUSION}

In general, the profile dimensions of each indicator are already visible, ranging from very good to good with a sequence as break: communication; empathy; authenticity; having a relationship; synchronization; and problem solving. With the evidence of the contribution of social intelligence that affect the results of social studies, the social intelligence to be developed in each individual.

The implication of this research is the development of materials in social studies can be focused on indicators that have not been optimally implemented so that every indicator of social intelligence can be owned by the students equally because in essence social intelligence is one of many factors that affect the results of social studies. In addition, teachers need to provide guidance to students on a regular basis with the event makrut bit errors can be quickly detected so that teachers can directly guide. The aim of this mentoring program to facilitate students in maintaining and improving social intelligence that has been held in accordance with the stage of growth and development.

\section{REFERENCES}

[1] Afrianti Nurul. (2015). Profil Kecerdasan Sosial Siswa SMA di Kota Bandung sebagi Studi Awal Penyelenggaraan Layanan Bimbingan Konseling. Jurnal Ilmiah Psikologi Terapan. 5(1): 57.

[2] Azwar, S. (2015). Pengantar Psikologi Intelegensi. Yogyakarta: Pustaka Pelajar

[3] Baggiyam, N. D. \& Mrs. Pankajam, R. (2017). Social Intelligence in Relation To Academic Achievement. International Journal of Research, 5(3): 18-22.

[4] Daniyati, N. A. \& Sugiman. (2015). Hubungan Antara Kemampuan Verbal, Kemampuan Interpersonal, dan Minat Belajar dengan Prestasi Belajar Matematika. Jurnal Pendidikan Matematika, 10(1): 50-60.

[5] Dalyono, M. 2012. Psikologi Pendidikan. Jakarta: Rineka Cipta.

[6] Djamarah, Syaiful Bahri. 2015. Psikologi Belajar. Jakarta: Rineka Cipta.

[7] Goleman, Daniel. 2018. Emotional Intelligence. Jakarta: Gramedia Pustaka Utama.

[8] Honeywill, Ross. 2015. The Man Problem: destructive masculinity in Western culture. Palgrave Macmillan: New York.

[9] Herwati, Kanaria. (2014). Implikasi Kecerdasan Interpersonal dan Motivasi Belajar terhadap Prestasi Belajar IPS. Research and Development Journal Of Education, 1(1): 36-44.

[10] Kriemeen, H. \& Sulaiman, H. (2017). Social Intelligence of Principals and Its Relationship with Creative Behavior. World Journal of Education, 7(3):84-91.

[11] Popp, Jerome. (2017). Social Intelligence and the Explanation of Workplace Abuse. SAGE Journal of Workplace Rights, 1-7.

[12] Rahim, Maryam dan Meiske Paluhulawa. (2018). Pengembangan Panduan Bimbingan dan Konseling untuk Mengembangkan Kecerdasan Sosial Siswa. Jurnal Psikologi Pendidikan dan Konseling, 4(2): 79.

[13] Slameto. 2010. Belajar dan Faktor-Faktor yang Mempengaruhi. Jakarta: Rineka Cipta.

[14] Subini, Nini. 2012. Mengatasi Kesulitan Belajar Pada Anak. Jogjakarta: Javalitera.

[15] Susanto, Ahmad. 2013. Teori Belajar dan Pembelajaran di Sekolah Dasar. Jakarta: Prenadamedia Group.

[16] Taneo, Silvester Petrus. 2010. Kajian IPS SD. Jakarta: Depdiknas. 